\title{
THE BULGARIAN INDUSTRY: THE STATE, DEVELOPMENT AND PROSPECTS OF INDUSTRIAL POLICY
}

\author{
Nikolay Sterev ${ }^{1}$ (D)
}

DOI: https://doi.org/10.31410/LIMEN.2019.31

\begin{abstract}
Bulgarian industry has the potential to become a crisis balancer as it reduces the negative impact of a financial crisis and drives the contemporary economic growth. In addition, not only the Bulgarian but European and world industries are developing at a rate unknown at this time. In just one generation, we have witnessed two major industrial revolutions (Industry 3.0 and Industry 4.0, respectively) and we are on the birth-stage of the next one (Industry 5.0). The success of an industrial enterprise, the success of the entire industry requires flexibility, adaptability and, above all, institutional support. So, the paper is addressed to research the following questions: 1. How the global industry is developing, 2. Where is the Bulgarian industry located and what are the opportunities for the development of Industry 4.0 via Internet 4.0, 3. What should be the next step in development of the Bulgarian industry.
\end{abstract}

Keywords: Industrial growth, Industrial development, Industry 4.0.

\section{INTRODUCTION}

$\mathrm{T}$

he main pillars within the industrial development could be found by analyzing the major changes of the industrial practices (main operational and management) in industry. Thus, the key points used in the assessment of the industry development are related to the change (or rather revolutionary) of the methods, approaches or tools for the establishment and / or operation of the industrial business and / or industrial sub-sectors. On this basis, „key” events can be highlighted, leading to a change in the development of industrial production. An example is the creation of a worldwide network - the Internet, which is currently changing the industry and its manufacturing and management-organizational processes from the inside out.

On this basis, five (resp. 4 past and 1 up-coming) major ,industrial revolutions” can be identified, leading to change throughout the world industry (Figure 1).

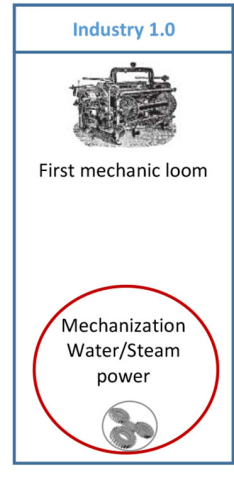

1784

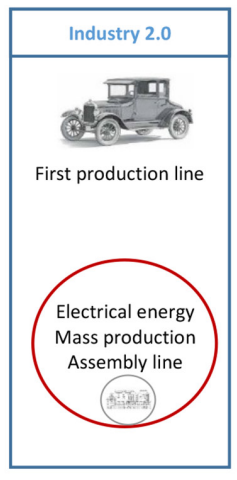

1870

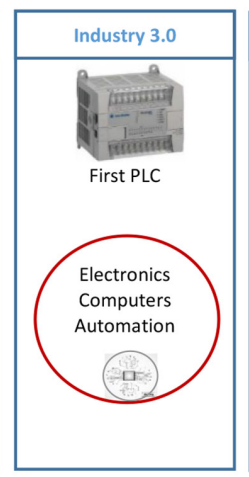

1969

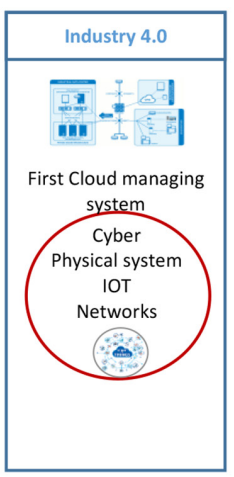

2009

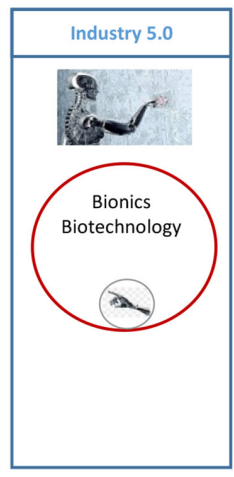

?2035?

Figure 1. Industry Revolution Stages

Source: Modification of T\&A (Taskforce \& Advisor Sàrl), https://www.ta-ad.biz/en/tindutrie-4-0

1 UNWE-Sofia, Head of Industrial Business Department at UNWE-Sofia, Chairman of Bulgarian Association of Professors of Economics and Management of Industry (APIUI), Bulgaria, 8 Decemvri, Studentski grad 
Analyzing the main characteristics of any change in industrial production, related to the „revolutionary" changes in the Industry and the interrelations between the basic production and organizational-managerial factors, we can summarize the five evolutionary stages in the development of the Industry, named „Industry x.0”:

- Industry 1.0: 18th Century Industrial Revolution, related to the mechanization of labor and the introduction of wind, water and steam (steam engine) into production technologies;

- Industry 2.0: 20th Century Industrial Revolution, related to the use of electricity (electric engine) and the use of a "New Organization" of Mass Production;

- Industry 3.0: Introducing computers to help manufacturing in the 1960s and 1970s. Production automation is achieved;

- Industry 3.5: Opening local economies globally. In the 1980s, a process of re-locating production according to production efficiency began. It is characterized by „export” of production from developed countries to underdeveloped economies;

- Industry 4.0: $21^{\text {st }}$ Century Industrial Revolution, related to Introducing Internet technologies into production. They allow the use of various cloud technologies, which leads to the so-called big data that is at the core of organizational excellence;

- Industry 5.0: Next Generation Industrial Revolution, related to introducing Bionics and Biotechnology into production. Allows the use of biological sensors to control and organize production. The challenge is to use an appropriate open source biological language to allow the use of biological / synthetic cells in industrial production.

\section{DEVELOPMENT OF THE BULGARIAN INDUSTRY}

Observing the key stages of worldwide industry development, an important issue for the Bulgarian industry could be found. Historically, there are several major kay points that link the development of the Bulgarian Industry to the global development:

- The Bulgarian industry began to develop in the first half of the 19th century with establishment of the very first industrial factory in Bulgaria: textile factory, in 1834. For the next 50 years the total number of established Bulgarian industry sites vary between 11 - 40 factories based on steam, water or animal power (Industry 1.0);

- At the end of $19^{\text {th }}$ century and in the beginning of $20^{\text {th }}$ century there is fast development of Bulgarian Industry as the Industry producers were encouraged through variety of tariff protections from foreign competition. The very first industrial protection law was adopted in 1894. Thus, from established 72 industrial factories with 3027 employees in 1894, the Bulgarian industry enlarges several times till 1912 with already established 389 industrial sites with 15560 employees. It is very important issue that there is start point of diversification of industries sub-sectors as development of: mining production, food production, textile and clothing production, tobacco production, etc. Between World War I and World War II, industrial development continued at an accelerated pace, with establishment of new-born business as there are established 3,815 enterprises (mostly small and medium-sized) with 87,442 employees in 1934. According to the official data, this industrial growth was based on development of the energy industry and the equipment of electricity-generating companies (Industry 2.0);

- The next restructuring of the Bulgarian industry began in 1947 after the nationalization that held on 23 December 1947. At that moment, there are 4628 enterprises with 158 127 employees. As a result, the „consolidation” of industrial businesses in the governmental rule is achieved, with close off almost $40 \%$ of existing industrial enterprises. A 
plan for accelerated industrialization and development of the heavy industry: chemical, metallurgical and mining industries is also adopted. After 1966, Bulgaria continues the course for accelerated industrialization, but the emphasis is on the modernization of production, as well as the mechanization and automation of production processes, incl. and the use of electronic learning machines in manufacturing. The basis is the acceleration of scientific and technological progress (Industry 3.0);

- The next change in the industrial structure of Bulgaria started in 1989 with the political changes in Central and Eastern countries. At the end of 1989 there are 2,593 industrial enterprises and 1.58 million people employed. A considerable number of enterprises were created, and with the adoption of the Privatization and Post-Privatization Control Act in 1992. Most of the state-owned enterprises are sold through mass and cash privatization. In a large part of the transactions, especially in the case of cash privatization, Bulgarian industrial enterprises become the property of foreign investors. With this industrial change, the Bulgarian industry becomes an integral part of the European industry as an ,important" element of European production chains (Industry 3.5) (Ivanov 2013,2015).

- In recent years, since 2000, a special emphasis in the development of industry has been the development of Internet technologies. Following the global development from Internet 1.0 to Internet 4.0, Bulgarian industrial companies are increasingly relying on the use of cloud technologies and big data in their operations. According to experts (Biolcheva 2017), over $40 \%$ of industrial enterprises use social networks, Internet of Things (IoT) and other Internet technologies in their businesses (Industry 4.0).

The transition of the Bulgarian Industry during the different stages of its development can be represented by the dynamics of the industrial production (Figure 2).

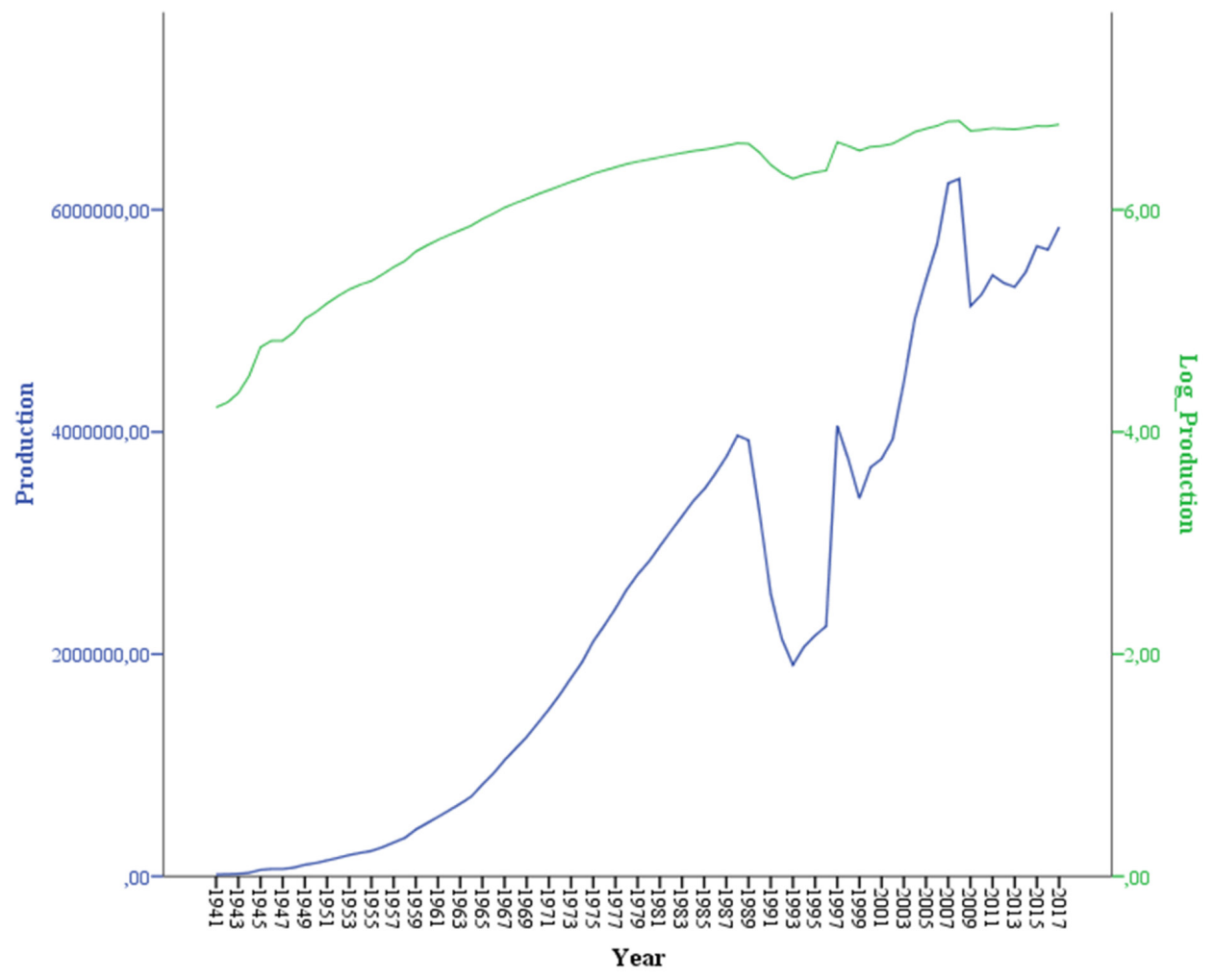

Figure 2. Dynamics of the industrial production in Bulgaria 1939-2018.

Source: Own Presentation and Modification by Kopeva D., D.Blagoev, N. Shterev, 2012 
The transition of the Bulgarian industry to Industry $\mathbf{5 . 0}$ is connected with the subsequent digitization of the production and organizational-management processes. On this basis, the development of the Bulgarian industry is directly related to the establishment and development of the so-called digital enterprises (ME 2017). The steps to be taken by the industrial business with the support of the Bulgarian Ministry of Economy can be reduced to the following more significant ones:

- Digitizing the company workflow - working instructions; production and organizational forms; purchase and delivery applications; product specifications;

- Real-time monitoring of production - working with wireless sensors and equipment that monitors production performance electronically (IoT: Internet of Things);

- Introduction of the so-called. smart processes based on machines and equipment that can monitor and analyze incoming information and make independent decisions;

- Connecting production to the Internet through various B2B and B2C Virtual Social networks.

\section{COMMON BULGARIAN INDUSTRIAL DEVELOPMENT FRAMEWORK}

Recognizing the challenge of the „expected” Fifth Industrial Revolution and securing the smooth shift from Industry 4.0 to Industry 5.0, the European Commission and the Europe Council have already prepared in 2014-2015 a number of operational documents, the most important of which is the European Industrial Renaissance Strategy (EC, 2014), based on the European Industry Report (EC, 2013a) and European Competitiveness Report (EC, 2013b).

The challenge to the governing Bulgarian industry is appoint to decide the task: how to use appropriate industrial policy instruments for different levels:

- macro-level with national / European industrial policy and digitalization strategies;

- meso-level with supporting establishment and development of industrial clusters and clusters of affiliated industrial enterprises;

- micro-level as encouraging usage of leadership approach.

Moreover, the positive impact that should be pursued through different company goals or sectoral and national strategies and policies is the realization of real dynamic development of the companies and the Bulgarian industry as well.

On this basis, an appropriate set of horizontally and vertically coupled strategies and operational measures based on the inter-firm cooperation (Slavova 2016) needed to be derived by adoption of national priorities for promoting Industry 4.0:

- Innovation Strategy for Smart Specialization (IS3) of the Republic of Bulgaria 2014-2020 and Intelligent Specialization Process

The strategic goal of IS3 is Bulgarian industry to move from the group of "stealthy innovators" to the group of "moderate innovators". In practice, this change in will be implemented through an effective policy to promote:

- Innovation, research and development of human capital (Milusheva 2016);

- investments in high-tech areas in which Bulgaria has traditions, has created specialists and successfully competes on the international market incl. transport and logistics (Yordanov 2019);

- export-oriented industries.

- Strategy for industrial Renaissance and re-industrialization program: a draft strategy has been prepared but has not been adopted in the final version. 
The thesis presented in the draft Strategy for industrial Renaissance is that two very important sides of support for the Bulgarian Industry (macroeconomics and business environment) are insufficient in the context of long-term real Renaissance of industry in Bulgaria. The significant problematic fields in the Bulgarian industry and the challenges of re-industrialization are not limited to the strengths and capabilities of companies and businesses in general, but to the horizontal and vertical connections inside the value-added chains. Without an active and focused government policy (s) and resulting supportive tools, the industry status quo is difficult, even impossible, to change.

- National SME Encouragement Strategy 2014-2020

With the Entrepreneurship 2020 - Bulgaria Action Plan, our country is committed to pursuing a policy of encouraging and setting up new businesses in the long run. The sources of funding for the measures are foreseen both within the approved budget of the responsible institutions, as well as from the operational programs of the European Structural Funds and the Commission's COSME program. Specific implementation measures are proposed for each area of action.

\section{CONCLUSION}

The development of the industry, both in Bulgaria and globally, goes through different evolutionary stages: from Industry 1.0 in 1784 (for Bulgaria - 1836) to Industry 4.0 in 2010. The key feature of this evolution is the achievement of continuous industrial growth, which is based on creating organizational excellence and bringing production and sales closer together through the digitization of business beyond 2010 .

On this basis, an appropriate set of horizontally and vertically coupled strategies and operational measures can be derived from the National priorities related to the promotion of Industry 4.0 (Iliev, Blagoev Shterev 2014):

- Develop and adopt Strategy for Industrial Renaissance with the active involvement of representatives of different sectors and stakeholders;

- Develop an Action Plan (Re-industrialization Roadmap) with specific activities, performance indicators and timelines;

- To propose appropriate mechanisms and tools, incl. financial programs, schemes and tools to ensure the implementation of the Action Plan and Strategy.

\section{ACKNOWLEDGMENT}

This research was supported by the University of National and Word Economy [grant number NID NI 18-2018] in contribution to the National Scientific Fund Project: Regional Indexing of Innovation Activity in Economic Sectors (IRISI) - scenarios over the four priority thematic areas for smart specialization identified in IS3 and their place in the circular economy [grant number OPR 01/4] 


\section{REFERENCES}

Biolcheva P., 2017, Stimulating innovation in start-ups, Proceedings of Conference: Modern logistics - business and management, UNWE-Sofia, October 2017, pp.336-344 (Bulgarian)

EC, 2013a, Towards knowledge-driven Reindustrialisation, [on-line] http://ec.europa.eu/enterprise/policies/industrial-competitiveness/competitiveness-analysis/europeancompetitiveness-report/files/eu-2013-eur-comp-rep_en.pdf

EC, 2013b, Industrial Performance Scoreboard, [on-line] http://ec.europa.eu/enterprise/policies/ industrial-competitiveness/monitoring-memberstates/files/scoreboard-2013_en.pdf

EC, 2014, For a European Industrial Renaissance, SWD (2014) 14 final, [on-line], http://cor.europa.eu/en/activities/stakeholders/Documents/Com\%202014-14.pdf

Iliev Y., N. Sterev, D. Blagoev, 2018, Industry of Bulgaria: Past, Present and Future, Proceedings of the Conference in Honor of the 130th Birthday of Prof. Dimitar Dobrev, IK-UNSS, Sofia (in Bulgarian)

Ivanov, I. 2013, The Bulgarian Defense Technological and Industrial Base (Contemporary Problems Before Its Functioning and Development). Proceedings from the Jubilee International Scientific Conference, UE - Varna (in Bulgarian)

Ivanov, I. 2015, Restructuring of the defense industry in Bulgaria at the end of XX and the beginning of XXI century (conflicting economic and historical essay), Proceedings from the International Scientific Student Conference on Economics, Politics and Management, Sofia, Publishing Complex - UNWE IK-UNSS, (in Russian)

Kopeva D., D.Blagoev, N. Shterev, 2012, Industrial dynamics in Bulgaria - the connection between past and future, 11th Comparative Analysis of Enterprise Data \& COST Conference 2012, 26-28 April 2012, Nuremberg, Germany, [on-line] http://doku.iab.de/fdz/events/2012/ Kopeva.pdf

Milusheva V., 2016, Aspects of company competitiveness evaluation, Proceedings of Scientific-applied conference: Strategic visions: Effective management for economic, organizational and social transformations (innovations - institutions - business), pp. 364-369, NBU, Sofia (in Bulgarian)

Ministry of Economy (Bulgarian), 2017, Digital Industry Transformation Strategy for Industry (Industry 4.0), https://www.mi.government.bg/files/useruploads/files/ip/kontseptsia_industria_4.0.pdf (in Bulgarian)

Rodrik, D., 2004, Industrial Policy for the Twenty-First Century, Harvard University

Slavova, P., 2016, Conditions of Productivity Processes in a Company of Food Industry in Bulgaria, Proceedings of $3^{\text {rd }}$ International Conference on New Challenges in Management and Organization: Organization and Leadership, 2 May 2016, Dubai, UAE, [on-line] https://www. sciencedirect.com/science/article/pii/S1877042816311478

Stoyanova T., N. Sterev, 2018, The role of measurements of OP Innovations and Competitiveness (OPIC) for intelligent growth of Bulgarian Economy, Local and Regional Economy in Theory and Practice - Conventional Generation in The Context Of Local And Regional Development, №395/2018, Wroclav, [on-line] http://cejsh.icm.edu.pl/cejsh/element/bwmeta1.element. desklight-f54fe02d-5076-4a21-a5bc-f37eb708ff17/c/Ekonomia_XXI_Wieku_2018_2_18_ Czesc7.pdf

T\&A (Taskforce \& Advisor Sàrl), https:/www.ta-ad.biz/en/tindutrie-4-0

Yordanov D., 2019, Consumer assessment of the quality of transport services and guidelines to increase their competitiveness, Economic Alternatives Journal, issue 4/2019, Sofia 